\title{
Identification of Maintainer Lines and Evaluation of Experimental Hybrids Derived from a Brazilian Tropical Onion Population
}

\author{
C.A.F. Santos ${ }^{1,}$, , D.L. Leite ${ }^{2}$, V.R. Oliveira ${ }^{3}$ and N.D. Costa ${ }^{1}$ \\ ${ }^{1}$ Embrapa-Semiárido, C. Postal 23, 56302-970 Petrolina - PE, Brazil \\ ${ }^{2}$ Embrapa Clima Temperado, C. Postal 403, 96001-970 Pelotas - RS, Brazil \\ ${ }^{3}$ Embrapa Hortaliças, C. Postal 218, 70359-970 Brasília - DF, Brazil
}

Keywords: Allium cepa, A and B lines, 'Alfa São Francisco'

\begin{abstract}
The four to five-fold price of onion hybrid seeds accounts for the wide use of open pollinated onion populations in Northeastern Brazil. Here we report the identification of maintainer and male-sterile onion lines within the 'Alfa São Francisco' yellow onion population, after three years of work, associating random field pairing of male-fertile plants with selected male-sterile plants and a PCR-based marker cytoplasm monitoring system. Male-sterile plants produced flowers with light green anthers which were easily detected in the field. A $2.0 \%$ frequency of male-sterile plants was estimated in the 'Alfa São Francisco' sampled population. Male-sterile plants produced the 5'cob-marker 180-bp and the orf A501-marker 473-bp fragments, suggesting the T-cytoplasm type, while the maintainer line produced only the 5'cobmarker 180-bp. Pairing ' $A$ ' line with a red onion resulted in $100 \%$ F1 red bulbs produced from harvested seed in the 'A line', confirming that a stable CMS system was identified within the Brazilian tropical 'Alfa São Francisco' population. Hybrids produced with another 'Baia periforme' onion population (Line ' $C$ ') and the ' $A$ ' identified lines' have resulted in a $38 \%$ bulb yield increase compared with the best parent, 'Alfa São Francisco'. The identified ' $A$ ' and ' $B$ ' lines, associated with other developed $S 1$ and $S 2$ populations (' $C$ ' lines) will be used to produced commercial hybrids well adapted to Brazilian low latitudes and with affordable prices for growers.
\end{abstract}

\section{INTRODUCTION}

In onion, the production of hybrid seed became economically feasible with the discovery of the cytoplasmic-gene male-sterility (CMS) system (Jones and Emsweller, 1936; Berninger, 1965). As reviewed by Szklarczyk et al. (2002), in addition to normal male-fertile N-cytoplasm, three different male-sterile cytoplasms have been used in onion hybrid seed production: ' $\mathrm{S}$ ' identified in the 'Italian Red' cultivar, ' $\mathrm{C}$ ' identified in the 'Rijnsburger' cultivar, and ' $\mathrm{T}$ ' identified in the 'Jaune paille des vertus' cultivar. The identification of the ' $\mathrm{N}$ ', ' $\mathrm{S}$ ' an ' $\mathrm{T}$ ' onion cytoplasms was greatly facilitated with the development of specific DNA markers associated to specific kinds of onion cytoplasms by Polymerase Chain Reaction (PCR) (Havey, 1995; Sato, 1998; Engelke et al., 2003).

The semiarid Brazilian region of the States of Pernambuco and Bahia account for $18 \%$ of the national onion production, and the most important cultivars grown are open pollinated (OPs). Two main reasons account for the wide use of OPs in the region: (i) the price of hybrid onion seeds is four to five-fold that of the OP seeds, and (ii) many available hybrids are susceptible to anthracnose caused by the Colletotrichum gloeosporioides fungus. Previous attempts to identify maintainer (line 'B') and malesterile lines (line 'A') (Leite, 1999; Costa, 1967) did not lead to the development of a commercial hybrid based on long-time adapted Brazilian onion populations.

We report the identification of lines 'A' and 'B' within the tropical onion 'Alfa São Francisco' population, based on random field pairing of fertile plants with selected sterile plants and a PCR marker system to monitor cytoplasm type, and also preliminary yield evaluation of onion hybrids developed with identified ' $A$ ' an ' $B$ ' lines in the São Francisco river Valley, Brazil.

a casantos@cpatsa.embrapa.br 


\section{MATERIAL AND METHODS}

Screening for male-sterile and maintainer plants was performed within the 'Alfa São Francisco' onion population, which was derived by phenotypic recurrent selection in the 'Alfa Tropical' onion population. 'Alfa Tropical' was developed by phenotypic recurrent selection in a base population constituted from an open polycross among eleven varieties of the 'Baia Periforme' onion type (Araújo and Rodrigues, 1998).

Sterile plants were identified in the field by visual identification of open flowers without pollen and they were randomly paired with surrounding fertile plants. After vernalization in a cold chamber, bulbs were grown in the field to produce seeds for a new screening. To be considered a potential maintainer, a pair had to have sterile progenies from the previous sterile plant and fertile progenies from the previous fertile plant. Three test-crossing were performed with selected pairs, one from 2005 to 2006, another from 2006 to 2007 and the last one from 2007 to 2008.

The total DNA was isolated from onion leaf tissue following the CTAB $2 x$ protocol, with minor modifications, such as extraction buffer with $2.0 \%$ beta-mercaptoethanol and incubation at $60^{\circ} \mathrm{C}$ for 30 min for all samples, with occasional mixing by gentle tube inversion. After RNAse treatment to remove co-isolated RNAs, the total DNA quantity and integrity were estimated on $0.8 \%$ agarose gels. PCR was performed as described by Engelke et al. (2003).

Onion cytoplasms were identified according to Engelke et al. (2003): i) Ncytoplasm - only the 180-bp fragment of the 5' cob-marker was amplified; ii) T-cytoplasm - the fragments 180-bp of the 5'cob-marker and 473-bp of orfA501were amplified; and iii) S-cytoplasm - fragments of 180-bp and 414-bp of the 5' cob-marker and fragment of 473-bp of $\operatorname{orfA501}$ were amplified.

Two hybrids, HA2-11S2 and HA1-11S2, were developed by crossing 'A' lines, identified within 'Alfa São Francisco', with an S2 from another 'Baia periforme' onion population. A complete randomized block experimental design was used, with six treatments and two replications, evaluated in the second semester, at Petrolina, PE, Brazil. Three treatments (HOAT, HOIP and HO64) were hybrids developed by Embrapa Vegetables Research (Brasilia, DF, Brazil) and one control, the parent population 'Alfa São Francisco'. The spacing among plants was $0.1 \times 0.15 \mathrm{~m}$, and a drip irrigation system was used. The heterosis vigor $(\mathrm{H})$ was estimated in relation to the parent 'Alfa São Francisco' by $\mathrm{H}=[(\mathrm{F} 1-$ Alfa $) /$ Alfa $] * 100$.

\section{RESULTS AND DISCUSSION}

Maintainer and male-sterile onion lines within the 'Alfa São Francisco' population were identified after two successive test-crossing performed in two years under Brazilian Semiarid conditions. Seed to seed production was possible in the region in one year: 1) onion bulbs can be produced in four months after sowing, 2) bulbs can be vernalized in a cold chamber for around hundred days, and 3) vernalized bulbs can produce seed in three to four months.

Male-sterile plants in the 'Alfa São Francisco' onion population produced easily detected flowers with light green anthers and when the anthers were squeezed between thumb and finger they did not leave a trace of pollen. Caging sterile plants with flies to force self-pollination did not produce seeds. A 2.0\% frequency of male-sterile plants was estimated in around 1,500 plants of the 'Alfa São Francisco' population.

Random field pairing of fertile plants with selected sterile plants produced 90 pairs and only one pair, the $16 \mathrm{E} 1(\mathrm{E}=$ sterile $) \times 16 \mathrm{~F}(\mathrm{~F}=$ fertile $)$, presented the onion CMS maintainer conditions in the first test-crossing. The potential maintainer 16F1F1 (meaning pair 16, first and second F1 meaning first and second test-crossings, respectively) repeated the same desired maintainer conditions. A third test-crossing was performed with maintainer $16 \mathrm{~F} 1 \mathrm{~F} 1$ with four other male-sterile plants, identified within a commercial 'Alfa São Francisco' seed production, reproducing the previous maintainer conditions. Banga and Petit (1958), in Holland, and Costa (1967), in Brazil, reported successful 
identification of maintainer lines by random pairing with male-sterile plants of the same onion landrace population after four years of field work.

Maintainer 16F1F1 plants produced only the 180-bp fragment of the 5' cob-marker, while sterile plants produced the 180-bp fragment of the 5'cob-marker and the 473-bp fragment of the orfA501-marker, suggesting that the $\mathrm{N}$ and T-cytoplasms were present in the 16F1F1 and male-sterile plants, respectively (Fig. 1). Monitoring plant pairs in the first test-crossing with the developed CMS primers made it possible to focus only on the potential maintainer $16 \mathrm{~F} 1 \mathrm{~F} 1$, discarding pair plants such as 6E2-E2 $\times 6 \mathrm{~F} 2 \mathrm{~F} 2$ (Fig. 2). The 40 PCR cycles were enough to amplify the small quantity of co-isolated mitochondrial DNA with total genomic DNA, without the laborious and expensive protocols to extract vegetable cytoplasm as originally demonstrated by Engelke et al. (2003).

When pairing the yellow ' $A$ ' line with a red onion ('IPA 8') to produce seeds, $100 \% \mathrm{~F} 1 \mathrm{red}$ bulbs was produced from harvested seed in the 'A line', confirming that a stable CMS system was identified within the Brazilian tropical 'Alfa São Francisco' population.

Hybrids produced with another 'Baia periforme' onion population (Line ' $\mathrm{C}$ ') and the ' $A$ ' identified lines resulted in a $38 \%$ bulb yield increase compared with the parent, 'Alfa São Francisco'. Only the hybrids derived from BRS Alfa São Francisco, HA2-11S2 and HA1-11S2, showed significant differences to the control treatment, with 34.0 and $30.2 \%$ heterosis vigor 35.9 and 34.9 ton/ha yield, respectively (Table 1). The identified ' $A$ ' and 'B' lines, associated with other developed S1 and S2 populations (' $C$ ' lines) will be used to produce commercial hybrids well adapted to Brazilian low latitudes and with affordable prices for growers.

\section{ACKNOWLEDGEMENTS}

This research was supported by the CNPq and BNB-ETENE-FUNDECI.

\section{Literature Cited}

Araújo, M.T. and Rodrigues, A.G. 1998. Alfa Tropical - nova cultivar de cebola de verão In: Congresso Brasileiro de Olericultura 38. EMBRAPA-CPATSA/SOB, Petrolina, PE. p.21.

Banga, O. and Petiet, J. 1958. Breeding male sterile lines Dutch onion varieties as preliminary to the breeding of hybrid varieties. Euphytica 7:21-30.

Berninger, E. 1965. Contribution à l'étude de la sterilité mâle de l'oignon (Allium cepa L.). Ann Amélior Plant 15:183-199.

Costa, C.P. da 1967. Estudo da esterilidade masculina e identificação de linhas complemenares (Nmsms) na variedade brasileira de cebola baia periforme precoce Piracicaba (Allium cepa L). PhD Thesis, Universidade de São Paulo, 32p.

Engelke, T., Terefe, D. and Tatlioglu, T. 2003. A PCR-based marker system monitoring CMS-(S), CMS-(T) and (N)-cytoplasm in the onion (Allium cepa L.). Theor. Appl. Genet 107:162-167.

Havey, M.J. 1995. Identification of cytoplasm using the polymerase chain reaction to aid in the extraction of maintainer lines from open-pollinated populations of onion. Theor. Appl. Genet. 90:263-268.

Jones, H. an Clarke, A. 1943. Inheritance of male sterility in the onion and the production of hybrid seed. Proc. Amer. Soc. Hort. Sci. 43:189-194.

Leite, D.L. 1999. Molecular characterization of cytoplasmic diversity in leek and SouthAmerican onion cultivars and sequencing of onion cDNAs. Ph.D. Thesis, University of Wisconsin-Madison, 120p.

Sato, Y. 1998. PCR amplification of CMS-specific mitochondrial nucleotide sequences to identify cytoplasmic genotypes of onion (Allium cepa L.). Theor. Appl. Genet. 96:367370.

Szklarczyk, M., Simlat, M., Jagosz, B. and Ba, G. 2002. The use of cytoplasmic markers in onion hybrid breeding. Cell Mol. Biol. Lett. 7:625-634. 


\section{Tables}

Table 1. Origin, yield and heterosis vigor of five onion hybrids evaluated in the second semester in Petrolina, PE, 2008.

\begin{tabular}{lllc}
\hline Treatment & \multicolumn{1}{c}{ Origin } & $\begin{array}{c}\text { Yield } \\
(\mathrm{kg} / \mathrm{ha})\end{array}$ & $\begin{array}{c}\text { Heterosis vigor to } \\
\text { 'Alfa São Francisco' } \\
(\%)\end{array}$ \\
\hline HA2-11S2 & Embrapa Semiárido & $35.9 \mathrm{~A}$ & 34.0 \\
HA1-11S2 & Embrapa Semiárido & $34.9 \mathrm{~A}$ & 30.2 \\
HOAT - CNPH & Embrapa Hortaliças & $31.3 \mathrm{AB}$ & 16.8 \\
HOIP - CNPH & Embrapa Hortaliças & 28.8ABC & 7.4 \\
ALFA SF TT C-V & Embrapa Semiárido & 26.8BC & - \\
HO64 - CNPH & Embrapa Hortaliças & 23.4C & -12.7 \\
\hline
\end{tabular}

Means followed by the same letter did not differ significantly by the Tukey test, $\mathrm{p}<0.05$.

\section{Figures}

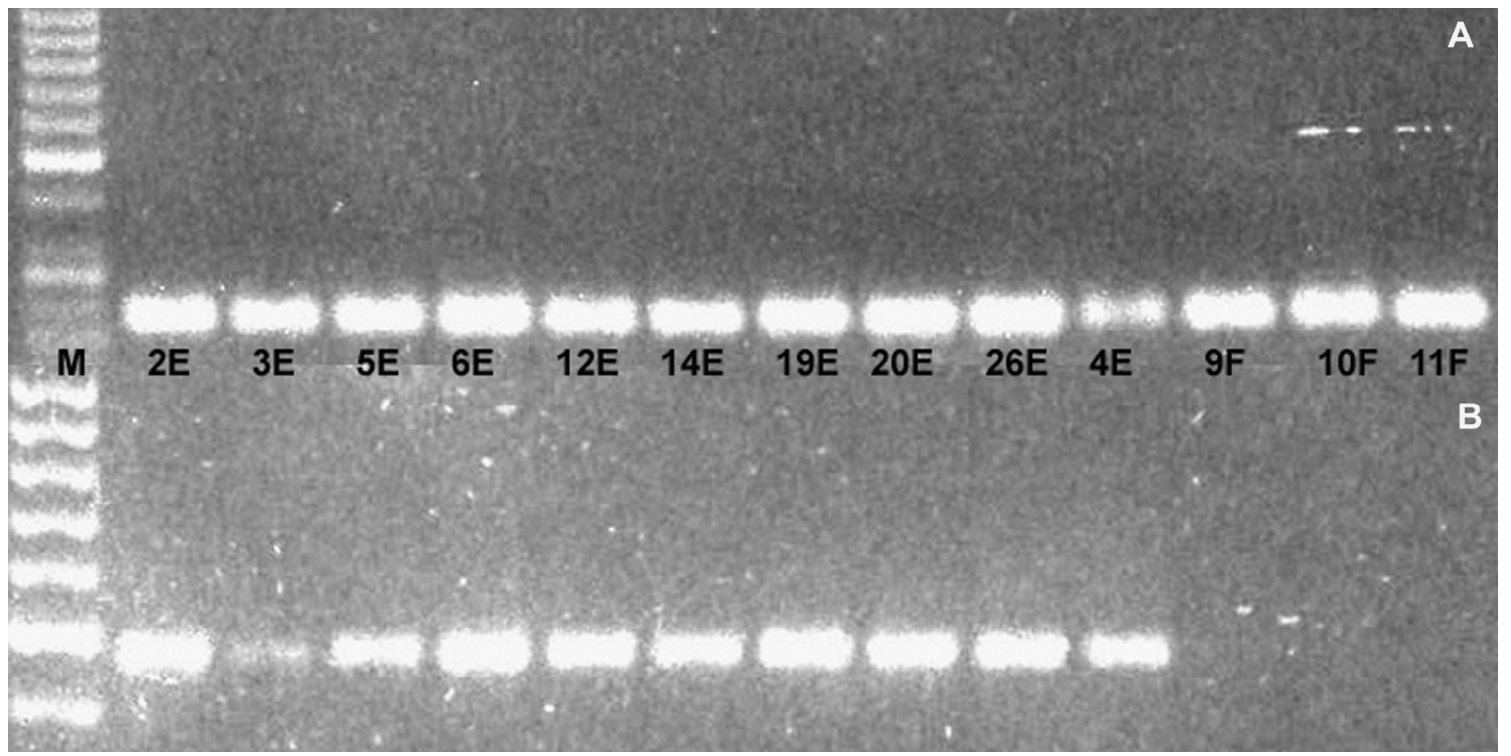

Fig. 1. Third test-crossing: the 5' cob-marker (Sato, 1998) (panel A) and the orfA501marker (Engelke et al., 2003) (panel B) in a bulk of lines 'A' and 'B' (16F1F1). $\mathrm{M}=$ DNA size marker $50 \mathrm{bp}$ Fermentas. 


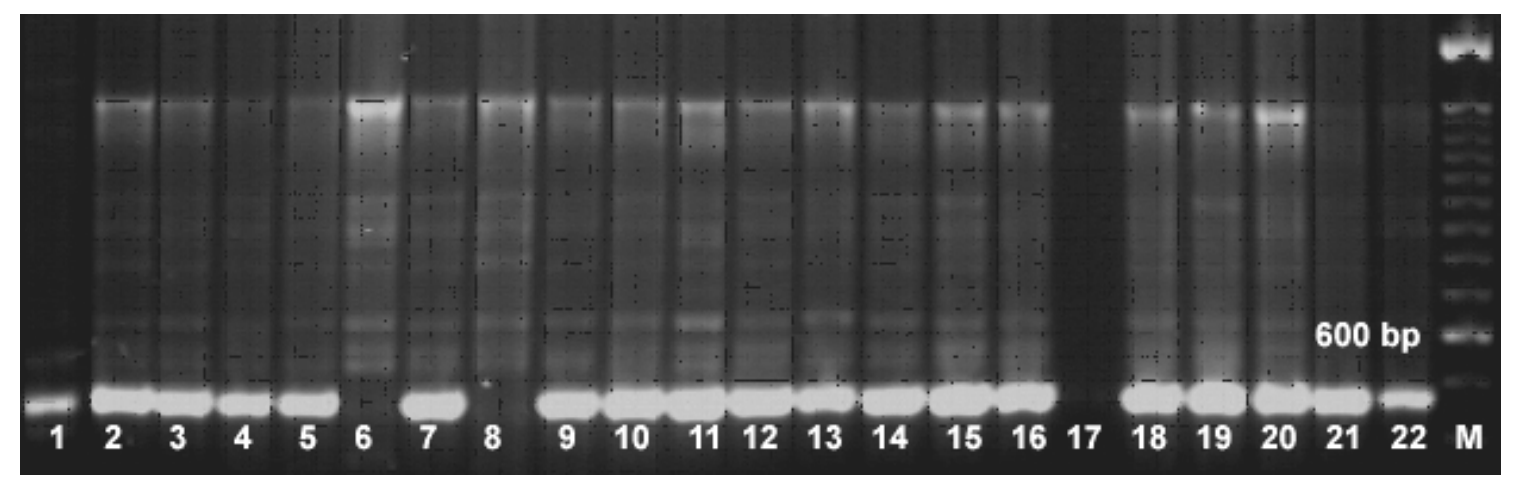

Fig. 2. Amplicons of the orfA501-marker in a first test-crossing of ten pairs of random field pairing of fertile plants $(F)$ with selected sterile plants $(E)$ of the 'Alfa São Francisco' onion population: (1) 6E2-E1 x (2) 6F2-F1, (3) 6E2-E2 x (4) 6F2F2, (5) 16E1E1 x (6) 16F1F1, (7) 16E1-E2 x (8) 16F1F2, (9) P27-E1, (10) 59E1 x (11) 59F1, (12) 31E1 x (13) 31F1, (14) 90E2 x (15) 90F2, (16) 90E3 x (17) 90F3, (18) 178-1E x (19) 178-1F, (20) P184-E1, (21) P188-E1, (22) Crioula 5. M = DNA size marker $100 \mathrm{~kb}$ plus. 
